\title{
THE EFFECTIVENESS OF SOLUTION FOCUSED BRIEF COUNSELING (SFBC) BASED ON CREATIVE ART TO REDUCE STUDENTS SOCIAL AGGRESSIVE BEHAVIOUR
}

\author{
Dhia Adinda Putri ${ }^{1}$, Wahyu Nanda Eka Saputra², Dody Hartanto 3 , Ariadi Nugraha ${ }^{4}$ \\ Universitas Ahmad Dahlan 1,2,3,4 \\ dhia1500001140@webmail.uad.ac.id ${ }^{1}$, wahyu.saputra@bk.uad.ac.id² ${ }^{2}, \underline{\text { dody.hartanto@bk.uad.ac.id }}^{3}$, \\ ariadi.nugraha@bk.uad.ac.id ${ }^{4}$
}

\begin{abstract}
The current study aimed to investigate the effectiveness of SFBC to decrease social agresive behaviour among the students of 12th grade in SMA Muhammadiyah 1 Prambanan. This study was an experiment study and used pre-experimental design employing one group pretest posttest model. The subject of this current study was students of 12th in SMA Muhammdiyah 1 Prambanan. In determining the subject, the researcher used nonprobablility sampling design with purposive sampling. The finding found a significant difference between students' social agresive level before and after they were treated with SFBC based on creative arts.
\end{abstract}

\section{ABSTRAK}

Penelitian ini bertujuan menyelidiki efektivitas SFBC untuk mengurangi perilaku sosial agresif pada siswa kelas XII di SMA Muhammadiyah 1 Prambanan. Penelitian ini adalah penelitian eksperimental dan menggunakan desain pra-eksperimental model pretest one group pretest. Subjek yang terlibat dalampenelitian ini adalah siswa kelas XII SMA Muhammadiyah 1 Prambanan. Dalam menentukan subjek, peneliti menggunakan desain nonprobability sampling dengan purposive sampling. Temuan ini menunjukan perbedaan yang signifikan antara tingkat agresif sosial siswa sebelum dan sesudah mereka diperlakukan dengan SFBC Berbasis Seni Kreatif.
Keywords:

social aggressive

behaviour,

solution focused

brief counseling

(SFBC) based on

creative art

Kata kunci:

Perilaku Agresif

Sosial, Solution

Focused Brief

Counseling

(SFBC) Berbasis

Seni Kreatif

Cara mengutip: Putri, D. A., Saputra, W. N. E., Hartanto, D., \& Nugraha, A. (2019). The Effectiveness of Solution Focused Brief Counseling (SFBC) Based on Creative Art to Reduce Students Social Aggressive Behaviour. Nusantara of Research : Jurnal Hasil-Hasil Penelitian Universitas Nusantara PGRI Kediri (eJournal), 6(2), 60-67. https://doi.org/10.29407/nor.v6i2.13616

\section{PENDAHULUAN}

Remaja merupakan harapan dalam mewujudkan cita-cita dari suatu bangsa. Remaja juga sebagai pihak yang memiliki pengaruh terhadap perubahan keadaan bangsa menuju bangsa yang lebih baik. Remaja sendiri berada pada masa perkembangan transisi dari fase anak-anak menuju ke fase dewasa yang memungkinkan terjadi berbagai perubahan, baik dari segi biologis, kognitif, juga emosional (Santrock, 2007). Remaja diharapkan memiliki karakteristik pribadi yang sehat mentalnya dalam aspek sosial sebagai berikut : (1) dapat berempati dan memiliki perasaan kasih sayang terhadap orang lain, serta gemar menolong orang lain yang pada saat itu membutuhkan bantuan (sikap altruis); (2) dapat menjalin hubungan dengan orang lain dengan sehat, dilandasi kasih sayang dan persahabatan; (3) 
bersifat toleran dan mampu menerima tanpa memandang status sosial, tingkat pendidikan, politik, agama, suku, ras atau warna kulit (Yusuf, 2011).

Namun pada kenyataannya remaja mempunyai sifat yang cenderung lebih agresif, emosi tidak stabil, dan tidak bisa menahan dorongan nafsu. Hal tersebut berdampak pada kemampuan remaja yang kesulitan untuk bisa beradaptasi dengan lingkungan di sekitarnya yang selalu berubah-ubah, sehingga muncul perilaku maladaptif, contohnya kekerasan sebagai bentuk perilaku agresi yang dapat menimbulkan kerugian pada orang lain, bahkan dirinya sendiri (Santrock, 2007). Perilaku agresif merupakan suatu luapan emosi sebagai reaksi terhadap kegagalan individu yang ditampakkan terhadap manusia atau benda dengan unsur kesengajaan yang diekspresikan dengan kata-kata (verbal) dan perilaku (non verbal) (Trisnawati \& Nauli, 2014).

Fenomena perilaku agresif masih sering dilakukan oleh siswa di sekolah terbukti dari penelitian yang dilakukan melalui wawancara dengan siswa SMKN 2 Pekanbaru pada tanggal 11 Januari 2014 bahwa semua siswa pernah melakukan perilaku agresif verbal, seperti mengumpat, menghina dan mengolok-olok dan 3 dari 5 siswa perna melakukan perilaku agresif fisik seperti memukul dan terlibat tawuran (Trisnawati \& Nauli, 2014). Wurbaton \& Anderson menggambarkan bentuk-bentuk perilaku agresif yang dapat menimbulkan kerugian bagi orang lain, yaitu: (1) agresi dalam bentuk fisik seperti menggigit, memukul, menusuk, dan menampar; (2) sakit hati yang berasal dari kata-kata kasar atau agresi verbal, seperti memanggil nama, berkata kotor, atau menghasut; dan (3) menyakiti persahabatan antara dua belah pihak. Perilaku agresif hingga saat ini masih menjadi permasalahan yang mengkhawatikan di kalangan remaja, terutama siswa di sekolah menengah. Siswa saat ini terkadang tidak sadar akan kompetensi dan potensi yang mereka miliki. Ketidaksadaran inilah yang membuat siswa melakukan tindakan-tindakan negatif yang berdampak terhadap dirinya sendiri dan lingkungan sekitarnya. Salah satu perilaku agresif yang sangat sering terjadi di kalangan siswa yaitu adalah agresif sosial. Perilaku agresif sosial merupakan perilaku yang harus segera dicari solusi pemecahannya karena berpotensi untuk dapat merusak atau menyakiti orang lain. Agresif sosial mencakup tidak langsung (misalnya, menyebarkan desas-desus), sedangkan agresif sosial langsung (misalnya, mengabaikan orang lain).

Konseptual tentang perilaku agresif sosial yaitu mengancam untuk mengakhiri pertemanan jika tidak melakukannya apa yang mereka inginkan, mengancam untuk mengucilkan jika tidak melakukan apa yang mereka inginkan, menolak untuk mendengarkan seseorang yang membuat mereka marah (Archer \& Coyne, 2005). Menurut Crick \& Grotpeter bahwa korban agresif sosial biasanya ditolak oleh rekan-rekan mereka dan akibatnya mengalami perasaan kesepian dan depresi. Namun konsekuensi dari agresif sosial bisa sangat serius. Penjelasan lebih dari Crick \& Grotpeter bahwa korban agresif sosial biasanya ditolak oleh rekan-rekan mereka dan akibatnya mengalami masalah penyesuaian sosiopsikologis (Martins \& Wilson, 2012).

Perilaku agresif umumnya dipicu oleh faktor tertentu, salah satunya adalah kondisi marah yang dapat memediasi munculnya perilaku agresif. Perasaan marah berkelanjutan akan terlampiaskan dalam bentuk perilaku tertentu, utamanya munculnya perilaku agresif (Sarwono 
\& Meinarno, 2009). Perilaku yang dilampiaskan individu ketika marah dapat berupa berkata kasar, mengejek, menghina sehingga dapat melukai harga diri individu lainnya. Sedangkan pemicu yang dapat menyebabkan munculnya perilaku agresif sosial pada remaja yaitu faktor internal (dari dalam) maupun faktor eksternal (dari luar). Faktor internal munculnya perilaku agresif adalah frustasi, gangguan pikiran, gangguan intelegensi, dan gangguan emosional remaja. Sedangkan faktor eksternal munculnya perilaku agresif sosial adalah keluarga, sekolah dan lingkungan (Kartono, 2006).

Banyak teori yang mempunyai pandangan tersendiri tentang perilaku agresif sosial, salah satunya adalah pendekatan Postmodern Counseling yaitu SFBC. Pemilihan pendekatan ini didasarkan pada asumsi bahwa setiap individu sehat, memiliki kompetensi, dan mampu membangun solusi yang mampu mengubah kondisi kehidupan mereka (Corey, 2015). Diharapkan dengan menggunakan pendekatan ini bahwa siswa mampu memiliki kompetensi dan berpotensi agar menjadi individu yang berkembang secara positif. Siswa terkadang sulit dalam mengungkapkan permasalahan yang dihadapi sehingga perilaku yang buruk terkadang tidak dapat mereka tangani sendiri yang menyebabkan terjadinya perilaku agresif sosial.

Model konseling yang biasa digunakan pada saat ini untuk menekan munculnya perilaku agresif sosial pada siswa cenderung menggunakan model konseling yang banyak membahas masalah, bukan berfokus pada solusi sehingga perilaku agresif sosial remaja dapat segera ditekan. Sehingga proses konseling yang terjadi cenderung lama dan banyak memakan waktu. Oleh sebab itu, dibutuhkan model konseling yang dalam prosesnya hanya memakan waktu yang relatif singkat, sehingga solusi segera ditemukan (Bannink, 2007). Dengan itu, siswa mampu fokus pada solusi dan bukan pada masalah, dan membantu mereka dalam mengembangkan kompetensi siswa dengan memanfaatkan berbagai sumber daya atau kekuatan yang dimiliki siswa. Tentunya hal ini menjadi perhatian para guru terutama konselor yang menjadi salah satu pihak penting yang dapat membantu siswa mengubah tingkah laku bermasalahnya.

Siswa diharapkan dapat mengkonstuk solusi melalui proses intervensi dengan mengembangankan media berbasis seni kreatif yaitu melalui menggambar solusi. Tujuan dari menggambar solusi adalah memberikan ekspresi konkret dari pertanyaan abstrak yang mengeksplorasi pengecualian untuk masalah, menggunakan pertanyaan keajaiban, dan mencapai penetapan tujuan (Degges-White \& Davis, 2017). Menggunakan seni kreatif siswa secara mandiri mampu menemukan solusi dalam mereduksi perilaku agresif sosial. Pendekatan yang sesuai untuk digunakan dalam setting sekolah adalah SFBC berbasis seni kreatif. Hal ini dasarnya adalah pendekatan konseling ini dapat dijalankan dengan prosedur yang relatif ringkas karena berorientasi pada pembangunan solusi terhadap masalah siswa. Selain itu, model konseling ini sangat menekankan pada kerjasama antara konselor dan konseli untuk membangun konsep diri siswa menjadi lebih positif. Dibuktikan dengan penelitian terdahulu tentang efektivitas SFBC untuk mereduksi perilaku agresif sosial siswa di salah satu Sekolah Menengah Atas (SMA) di Kabupaten Tuban, Jawa Timur. Hasil dari penelitian tersebut menyatakan bahwa terjadi penurunan perilaku agresif yang signifikan setelah dilakukan intervensi SFBC (Fitriyah, 2014). Sehingga, berdasarkan pemaparan hasil-hasil penelitian di 
atas, maka tujuan penelitian ini adalah untuk mengetahui keefektifan SFBC berbasis seni kreatif untuk mereduksi perilaku agresif sosial.

Upaya yang dapat dilakukan untuk mengurangi perilaku agresif sosial adalah melalui intervensi yang diharapkan, sehingga dapat membantu siswa mengkonstruk solusi. Proses yang akan dilakukan dalam SFBC berbasis seni kreatif menggunakan lima tahap, yaitu (1) mengembangkan hubungan; (2) identifikasi keluhan bermasalah; (3) mengembangkan tujuan; (4) merancang dan mengimplementasikan solusi; (5) terminasi dan tindak lanjut. Dimana pemberian layanan menggunakan seni kreatif mampu menghantarkan solusi yang diharapkan dari siswa sendiri. Proses mengkonstruk solusi dilakukan dengan menggunkan tiga teknik yaitu (1) pertanyaan berskala (scalling question); (2) pertanyaan keajaiban (miracle question); (3) mengembangkan tujuan.

SFBC berbasis seni kreatif sesuai untuk diterapkan pada seting sekolah, karena pada pendekatan ini berfokus pada kekuatan siswa daripada kekurangannya, dengan waktu yang relatif singkat, penekanan pada pembangunan solusi, dan ketercapaian pada tujuan (Nugroho, Puspita, \& Mulawarman, 2018). Tujuan konselor menggunakan seni kreatif dalam proses konseling adalah untuk memberikan dampak yang signifikan terhadap proses konseling yang menggunakan kerangka kerja SFBC (Nims, 2007). Penggunaan seni kreatif seperti musik, seni visual, drama, dan sebagainya dalam konseling dapat mengoptimalkan kinerja konselor dalam mengimplementasikan konseling yang inovatif (Saputra \& Sofiana, 2016; Saputra, 2017). SFBC sendiri sangat dimungkinkan untuk diintegrasikan dengan seni kreatif untuk meningkatkan keefektifannya, model tersebut diberi nama Creative Solution Focused Counseling Model (CSFCM) (Saputra, Da Costa, \& Alhadi, 2018). Litelatur yang lain juga menyebutkan bahwa SFBC sangat dimungkinkan untuk diintegrasikan dengan seni visual, yang disebut dengan teknik drawing solution (Saputra, Wiretna, Utami, \& Ramadhani, 2018. Berdasarkan pemaparan di atas, maka tujuan pada penelitian ini adalah untuk mengetahui keefektifan SFBC berbasis seni kreatif untuk mereduksi perilaku agresif sosial pada siswa.

\section{METODE}

Penelitian ini menggunakan pendekatan penelitian kuantitatif dengan desain penelitian eksperimen untuk melihat keefektifan SFBC berbasis seni kreatif untuk mereduksi perilaku agresif sosial siswa kelas XII di SMA Muhammadiyah 1 Prambanan. Bentuk desain penelitian yang akan digunakan adalah pre-experimental design dengan menggunakan model one group pretest posttest.

Instrumen yang digunakan dalam penelitian menggunakan 2 (dua) instrumen yaitu skala agresif sosial dan pedoman observasi. Skala agresif sosial terdiri dari 51 item pernyataan yang sudah tervalidasi. Dengan nilai koefisien alpha cornbach pada penelitian ini adalah 0,961, maka dapat disimpulkan bahwa termasuk dalam kategori reliabilitas tinggi. Pedoman observasi digunakan setelah pelaksanaan treatment dan posttest telah selesai. Lembar pedoman observasi juga dibuat sesuai dengan indikator pada agresif sosial.

Pada penelitian ini menggunakan skala perilaku agresif sosial yang telah teruji validitas dan reliabilitasnya. Kemudian skala perilaku agresif sosial tersebut disebarkan pada 
siswa SMA Muhammadiyah 1 Prambanan. Penelitian ini memilih data yang relevan dan data yang ditetapkan sebagai jawaban dari subjek penelitian yang dapat menggambarkan tingginya perilaku agresif sosial pada siswa kelas XII di SMA Muhammadiyah 1 Prambanan. Data penelitian ini terkumpul dalam bentuk kuantitatif (angka) sehingga analisis menggunaan statistik. Statistik yang digunakan untuk analisis data dalam penelitian ini menggunakan statistik inferensial. Penggunaan analisis data statistik pada penelitian ini menggunakan rumus t-test dengan bantuan program Statistical Package For Social Sciens (SPSS) versi 16.0 untuk mencari tingkat penurunan perilaku agresif sosial siswa.

\section{HASIL}

Pelaksanaan penelitian dilakukan dengan memberikan treatment sebanyak 5 kali pertemuan kepada 5 siswa yang terpilih dari hasil pretest. Setiap pertemuan memiliki sesi yang berbeda-beda sesuai dengan tahapan pada SFBC berbasis seni kreatif yaitu (1) mengembangkan hubungan; (2) identifikasi keluhan bermasalah; (3) mengembangkan tujuan; (4) merancang dan mengimplementasikan solusi; (5) terminasi dan tindak lanjut. Seni kreatif yang digunakan dalam penelitian ini adalah konselor mengajak konseli untuk membayangkan perilaku agresif sosial dan mencari jalan keluar untuk mengurangi perilaku agresif sosial tersebut dengan cara menggambar di lembar tugas. Kemudian konseli diminta untuk memaparkan secara langsung makna dari gambar yang telah dibuat.

Hasil penelitian ini menjelaskan dua bagian yaitu penurunan nilai dari hasil penyebaran skala perilaku agresif sosial antara pretest ke posttest serta hasil uji signifikansi dengan menggunakan rumus t-test. Data dari hasil pretest dan posttest mengenai perilaku agreif sosial selanjutnya diolah menggunakan microsoft excel. Hasil pretest dan posttest skala perilaku agresif sosial siswa kelas XII SMA Muhammadiyah 1 Prambanan adalah sebagai berikut:

Tabel 1.1. Deskripsi Skor Agresif Sosial Siswa Kelas XII SMA Muhammadiyah 1 Prambanan

\begin{tabular}{|c|c|c|c|c|c|c|}
\hline \multirow{2}{*}{ No } & \multirow{2}{*}{ Subjek } & \multicolumn{4}{|c|}{ Skor dan Kategori } & \multirow{2}{*}{$\begin{array}{l}\text { Gain } \\
\text { (d) }\end{array}$} \\
\hline & & \multicolumn{2}{|c|}{ Pretest } & \multicolumn{2}{|c|}{ Posttest } & \\
\hline 1 & DFY & 158 & Tinggi & 103 & Sedang & 55 \\
\hline 2 & AFW & 154 & Tinggi & 80 & Rendah & 74 \\
\hline 3 & HGS & 156 & Tinggi & 81 & Rendah & 75 \\
\hline 4 & $\mathrm{HN}$ & 155 & Tinggi & 89 & Rendah & 66 \\
\hline 5 & $\mathrm{FN}$ & 158 & Tinggi & 73 & Rendah & 85 \\
\hline Total & $\mathrm{N}=5$ & 781 & & 426 & & $\sum d=355$ \\
\hline \multicolumn{2}{|c|}{ Mean } & 156,2 & & 85,2 & & 71 \\
\hline
\end{tabular}

Pada tabel di atas dapat dijelaskan bahwa terjadi penurunan perilaku agresif sosial pada siswa dari yang berada pada kategori tinggi menurun menjadi kategori sedang dan rendah. Kategori sedang berjumlah satu (1) subjek yaitu DFY, sedangkan kategori rendah berjumlah empat (4) subjek yaitu AFW, HGS, HN, dan FN. Sebelum treatment diberikan, skor rata-rata dari agresif sosial pada siswa yaitu 156,2 sedangkan setelah diberikan treatment skor rata-rata agresif sosial siswa menjadi 85,2. Maka dari hasil pretest dan posttest yang telah dilakukan oleh konseli terjadi penurunan dengan skor rata-rata sebesar 71. Hasil penelitian ini juga menunjukan bahwa penurunan perilaku agresif sosial siswa yang paling besar yaitu pada 
subjek FN dengan skor sebesar 85 . Sedangkan penurunan paling rendah terjadi pada subjek DFY dengan skor sebesar 55.

Secara visual penurunan perilaku agresif sosial pada siswa kelas XII SMA Muhammadiyah 1 Prambanan dapat dilihat pada grafik berikut ini:

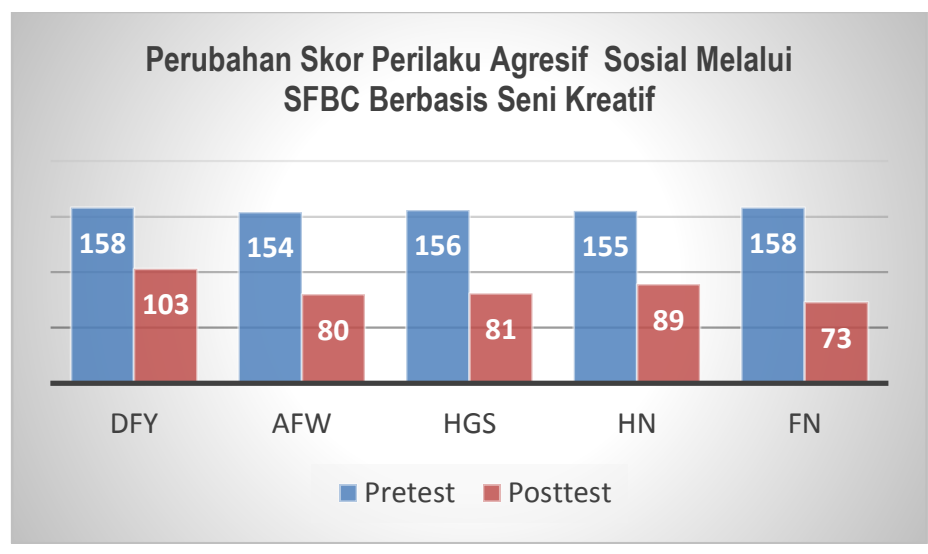

Gambar 1.1. Posisi ditengah ditulis dengan font arial narrow (10)

Berdasarkan gambar grafik di atas dapat diketahui bahwa terjadi penurunan perilaku agresif sosial setelah mengikuti layanan dengan SFBC berbasis seni kreatif. Hal ini dapat dilihat dari grafik posttest yang berwarna merah lebih rendah dari grafik pretest yang berwarna biru. Oleh karena itu, berdasakan gambar grafik tersebut dapat ditarik kesimpulan bahwa terdapat penurunan skor perilaku agresif sosial siswa setelah dilakukannya layanan dengan pendekatan SFBC berbasis seni kreatif.

Tabel 1.2. Hasil Penilaian t-hitung Paired Sample Test

\begin{tabular}{|c|c|c|c|c|c|c|c|c|c|}
\hline & & \multicolumn{5}{|c|}{ Paired Differences } & \multirow{3}{*}{$t$} & \multirow{3}{*}{$d f$} & \multirow{3}{*}{$\begin{array}{c}\text { Sig. } \\
\text { (2-tailed) }\end{array}$} \\
\hline & & \multirow[t]{2}{*}{ Mean } & \multirow[t]{2}{*}{$\begin{array}{c}\text { Std. } \\
\text { Deviation }\end{array}$} & \multirow[t]{2}{*}{$\begin{array}{l}\text { Std. } \\
\text { Error } \\
\text { Mean }\end{array}$} & \multicolumn{2}{|c|}{$\begin{array}{l}95 \% \text { Confidence } \\
\text { Interval of the } \\
\text { Difference }\end{array}$} & & & \\
\hline & & & & & Lower & Upper & & & \\
\hline Pair 1 & $\begin{array}{l}\text { Pretest - } \\
\text { Posttest }\end{array}$ & $\begin{array}{c}7.10000 \\
E 1\end{array}$ & 11.20268 & 5.00999 & 57.09004 & 84.90996 & 14.172 & 4 & .000 \\
\hline
\end{tabular}

Berdasarkan pada perhitungan di atas diperoleh nilai $t_{\text {hitung }}=14,172>2,131(\mathrm{t}$ tabel) pada taraf signifikansi $(\alpha)=5 \%$ sehingga Ho ditolak yang menunjukan bahwa ada penurunan perilaku agresif sosial siswa yang signifikan setelah diberikan SFBC berbasis seni kreatif pada siswa kelas XII SMA Muhammadiyah 1 Prambanan. Oleh karena itu, hipotesis penelitian yang berbunyi: "SFBC berbasis seni kreatif efektif untuk mereduksi perilaku agresif sosial pada siswa kelas XII SMA Muhammadiyah 1 Prambanan" teruji kebenarannya.

\section{PEMBAHASAN}

Hasil penelitian ini menyimpulkan bahwa SFBC berbasis seni kreatif efektif dan dapat dijadikan sebagai alternatif bantuan untuk mereduksi perilaku agresif sosial. SFBC berbasis seni kreatif merupakan salah satu intervensi yang dapat digunakan oleh guru BK untuk mereduksi perilaku agresif sosial siswa. Pendekatan ini sebenarnya juga percaya bahwa setiap individu memiliki solusinya sendiri untuk permasalahan individu tersebut, akan tetapi terkadang 
mereka lupa dengan potensi yang dimiliki karena selalu memandang masalahnya (Corey, 2015).

Hal tersebut sesuai dengan keadaan individu yang memiliki perilaku agresif sosial tinggi, yang menganggap bahwa perilaku agresif sosial dapat direduksi dengan usaha yang sunguh-sungguh. Akan tetapi perilaku tersebut dilakukan dalam keadaan sadar dan berdampak pada hubungan sosialnya. Namun tidak kunjung mencoba untuk mencari solusi akan masalahnya tersebut. SFBC berbasis seni kreatif ini diberikan pada siswa yang memiliki percaya bahwa dengan perubahan yang berkesinambungan akan membuat siswa mampu mereduksi perilaku agresif sosial.

Penelitian yang telah dilakukan sebelumnya menyimpulkan bahwa SFBC yang diterapkan pada seting konseling kelompok efektif mengurangi perilaku agresif siswa SMA. Analisis yang dilakukan menunjukkan bahwa pernyataan siswa yang awalnya menunjukkan perilaku agresif tinggi berubah menjadi pernyataan yang menunjukkan perilaku agresif rendah (Sari, 2014). Akan tetapi dalam penelitian ini konseling ringkas berfokus solusi digunakan untuk mengurangi perilaku agresif secara umum sedangkan penelitian yang dilakukan yaitu untuk mereduksi perilaku agresif sosial, sehingga peneliti dan pembaca lainnya dapat mengetahui secara runtut dampak dari perilaku agresif yang berhubungan dengan hubungan sosial. Dimana dengan melakukan agresif sosial ternyata dapat merusak jalinan sosial di lingkungan sekolah.

Selain itu penelitian yang dilakukan oleh Wahyu Nanda Eka Saputra dan Irvan Budhi Handaka pada tahun 2018 dengan judul Perilaku Agresi pada Siswa SMK di Yogyakarta. Hasil Penelitian tersebut dapat disimpulkan bahwa permasalahan perilaku agresi pada siswa SMK masih menjadi topik masalah. Penelitian ini menunjukkan bahwa (a) kategori sangat tinggi sebesar 5\%; (b) kategori tinggi sebesar 26\%; (c) kategori sedang sebesar 40\%; (d) kategori rendah sebesar $21 \%$ dan (e) kategori sangat rendah sebesar $8 \%$ (Wahyu Nanda Eka Saputra, 2018). Perbedaan dari penelitian ini adalah peneliti akan melakukan penelitian mendalam tentang perilaku agresif sosial.

Berdasarkan beberapa penelitian sebelumnya yang menyatakan bahwa telah berhasil membuktikan efektivitas penggunaan SFBC untuk mengatasi berbagai macam permasalahan. Penelitian ini juga membuktikan bahwa SFBC telah terbukti efektif untuk menurunkan perilaku agresif sosial.

\section{KESIMPULAN DAN SARAN}

Hasil dari proses penelitian ini dan pengamatan yang sudah dilaksanakan oleh peneliti, dapat dilihat bahwa terdapat penurunan perilaku agresif sosial setelah diberikan treatment. Oleh karena itu, dapat ditarik kesimpulan bahwa layanan SFBC berbasis seni kreatif dapat digunakan untuk mereduksi perilaku agresif sosial pada siswa.

Penelitian ini memberikan dasar bagi pengembangan penelitian selanjutnya dalam meneliti perilaku agresif sosial menggunakan pendekatan SFBC berbasis seni kreatif. Diharapkan dengan adanya penelitian ini dapat menjadi acuan untuk lebih mengembangakan kembali pelaksaan layanan konseling dengan menggunakan pendekatan SFBC serta sebagai upaya pengembangan layanan konseling berbasis seni kreatif. 


\section{DAFTAR RUJUKAN}

Archer, J., \& Coyne, S. M. (2005). An integrated review of indirect, relational, and social aggression. Personality and Social Psychology Review, 9(3), 212-230.

Bannink, F. P. (2007). Solution-focused brief therapy. Journal of Contemporary Psychotherapy, 37(2), 87-94.

Corey, G. (2015). Theory and practice of counseling and psychotherapy. Nelson Education.

Degges-White, S., \& Davis, N. L. (2017). Integrating the expressive arts into counseling practice: Theory-based interventions. Springer Publishing Company.

Fitriyah, F. (2014). Efektivitas Konseling Singkat Berfokus Solusi Untuk Mereduksi Perilaku Agresif Siswa: Penelitian Subjek Tunggal terhadap 6 Siswa SMAN 1 Singgahan Kabupaten Tuban Tahun Ajaran 2013/2014 (PhD Thesis). Universitas Pendidikan Indonesia.

Kartono, K. (2006). Psikologi Anak (Psikologi Pembangun). Bandung: Mandar Maju.

Martins, N., \& Wilson, B. J. (2012). Social aggression on television and its relationship to children's aggression in the classroom. Human Communication Research, 38(1), 4871.

Nims, D. R. (2007). Integrating play therapy techniques into solution-focused brief therapy. International Journal of Play Therapy, 16(1), 54.

Santrock, J. W. (2007). Remaja. Jakarta: Erlangga.

Sari, D. K. (2014). Keefektivan Konseling Kelompok Ringkas Berfokus Solusi Untuk Mengurangi Perilaku Agresif Siswa SMA. DISERTASI Dan TESIS Program Pascasarjana UM.

Sarwono, S. W., \& Meinarno, E. A. (2009). Psikologi Sosial. Jakarta: Salemba Humanika.

Saputra, W. N. E., Da Costa, A., \& Alhadi, S. (2018). Creative Solution Focused Counseling Models (CSFCM): Strategi Kreatif untuk Mengembangkan Self-regulated Learning Siswa. Jurnal Kajian Bimbingan dan Konseling, 3(4), 162-170.

Saputra, W. N. E., \& Sofiana, A. (2016). Konseling Inovatif Berbantuan Seni Kreatif.

Saputra, W.N.E., Wiretna, C.D., Utami, S.R. and Ramadhani, A., 2018. Drawing Solution: Ekspresi Seni dalam Konseling Ringkas Berfokus Solusi. Jurnal Fokus Konseling, 4(2), pp.185-191.

Saputra, W. N. E. (2017). Musik dan Konseling: Sebuah Inovasi Dengan Mengintegrasikan Seni Kreatif Dalam Konseling. In Prosiding Seminar Bimbingan dan Konseling (Vol. 1, No. 1, pp. 395401).

Saputra, W. N. E. (2018). Perilaku Agresi Pada Siswa SMK di Yogyakarta. Jurnal Fokus Konseling, 4(1).

Yusuf, S. (2011). Mental Hygiene: Terapi Psiko-spiritual untuk Hidup Sehat Berkualitas. Bandung: Maestro

Trisnawati, J., \& Nauli, F. A. (n.d.). Faktor-Faktor yang Mempengaruhi Perilaku Agresif Remaja di Smk Negeri 2 Pekanbaru. Jurnal Online Mahasiswa Program Studi IImu Keperawatan Universitas Riau, 1(2), 1-9. 